\title{
Estimating the scale of stone axe production: A case study from Onega Lake, Russian Karelia
}

\author{
Alexey Tarasov ${ }^{1}$ and Sergey Stafeev ${ }^{2}$ \\ 1. Institute of Linguistics, Literature and History, Pushkinskaya st.11, 185910 Petrozavodsk, Russia, \\ Email: taleksej@drevlanka.ru \\ 2. Institute of Applied Mathematical Research, Pushkinskaya st.11, 185910 Petrozavodsk, Russia, \\ Email: staf@sampo.ru
}

\begin{abstract}
:
The industry of metatuff axes and adzes on the western coast of Onega Lake (Eneolithic period, ca. $3500-1500$ cal. BC) allows assuming some sort of craft specialization. Excavations of a workshop site Fofanovo XIII, conducted in 2010-2011, provided an extremely large assemblage of artefacts (over 350000 finds from just $30 \mathrm{~m}^{2}$, mostly production debitage). An attempt to estimate the output of production within the excavated area is based on experimental data from a series of replication experiments. Mass-analysis with the aid of image recognition software was used to obtain raw data from flakes from excavations and experiments. Statistical evaluation assures that the experimental results can be used as a basement for calculations. According to the proposed estimation, some $500-1000$ tools could have been produced here, and this can be qualified as an evidence of "mass-production".
\end{abstract}

Keywords: Lithic technology; Neolithic; Eneolithic; Karelia; Fennoscandia; stone axe; adze; gouge; craft specialization; mass-analysis; image recognition

\section{Introduction}

\subsection{Chopping tools of the Russian Karelian type; Cultural context and chronological framework}

This article is devoted to quite a small and narrow question, which belongs to a much wider set of problems associated with an industry of wood-chopping tools of the so-called Russian Karelian (Eastern Karelian) type from the territory of the present-day Republic of Karelia of the Russian Federation. (See Figures $1 \& 2$.) The industry is dated to the period ca. $3500-1500$ cal. BC basing on radiocarbon dating from the sites with different varieties of Asbestos Ware, which usually contain these tools (Zhulnikov 1999: 76-77; Kosmenko 2003; Zhulnikov et al. 2012). This period is labelled as Eneolithic in the Karelian research tradition due to presence of tiny pieces of native copper in some assemblages.

In neighbouring Finland, where synchronous sites belonged to generally the same cultural tradition, this period is not separated from the Neolithic. (See Nordqvist \& Herva

Published by the School of History, Classics and Archaeology, University of Edinburgh ISSN: 2055-0472. URL: http://journals.ed.ac.uk/lithicstudies/

This work is licensed under a Creative Commons Attribution 2.5 UK: Scotland License. 
2013). The subsistence system in both Finland and Karelia was still largely based on hunting and gathering with a great deal of exploitation of aquatic resources (Savvateev \& Vereschagin 1978; Kotivuori 1993; Halen 1994: 164; Pesonen P. 1996: 112; Ukkonen 1996: 78; Koivunen 1997: 50; Karjalainen 1999: 186; Leskinen 2002: 168; Katiskoski 2002: 194; Pesonen P.2006: 204; Mökkönen 2011: 37), although there are indirect evidences of small-scale agriculture, quite numerous at the moment but still very controversial (Mökkönen 2010; Lahtinen \& Rowley-Conwy 2013). Despite the hunter-gatherer's economy, we can suspect remarkable degree of sedentism basing on the spread of long-term semi-subterranean dwellings, exceeding $50 \mathrm{~m}^{2}$ and in some cases even $100 \mathrm{~m}^{2}$ (Zhulnikov 2003: 126-127; Mökkönen 2011: 29-65). Presence of large houses and active participation in long-distance exchange gave reasons to some researchers to propose considerable degree of cultural and social complexity (Tarasov 2006; Costopoulos et al. 2012 and references cited).

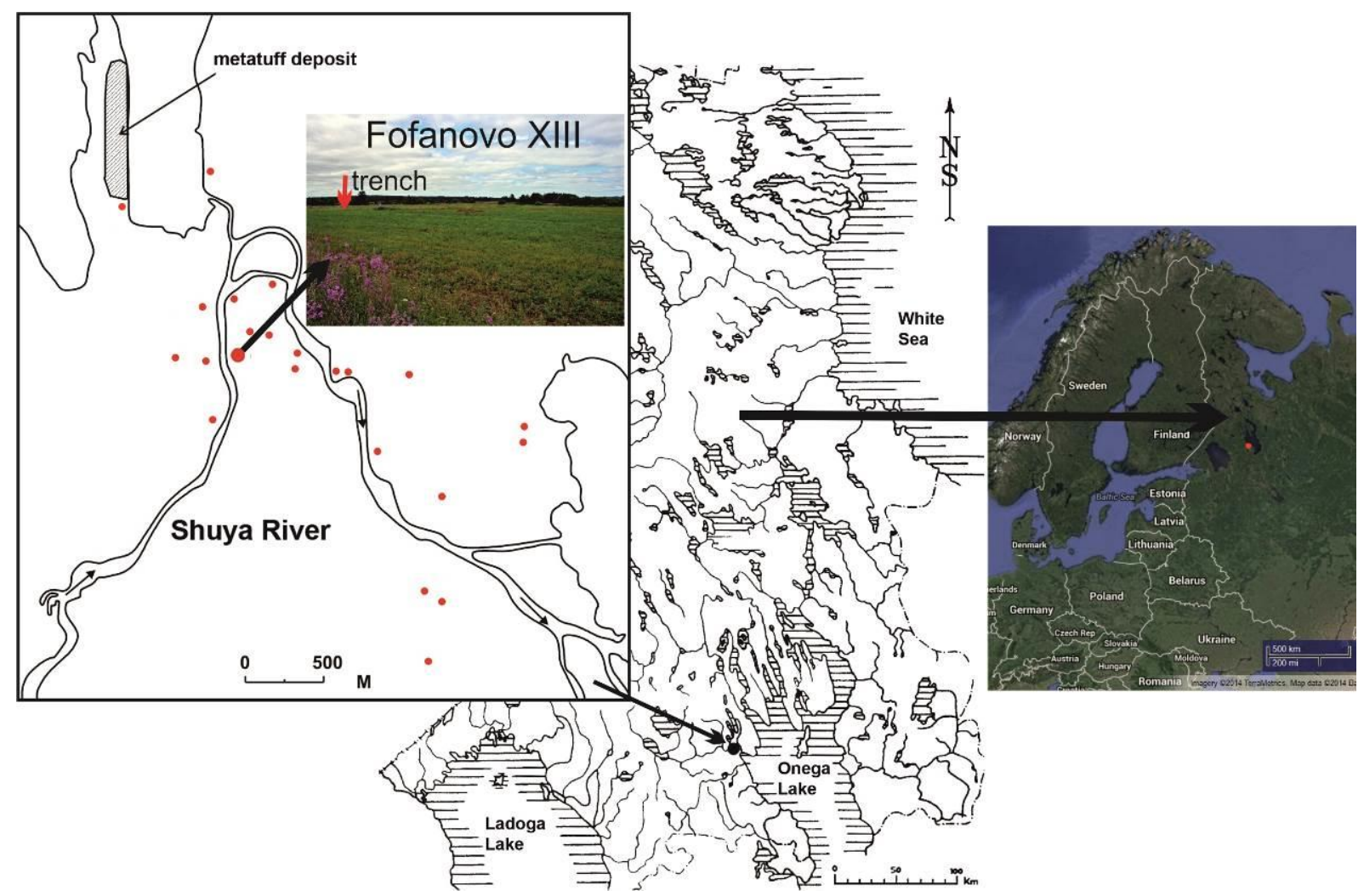

Figure 1. Location of workshop sites for making metatuff chopping tools of the Russian Karelian type in the outfall of Shuya River on the western coast of Onega lake. World Map data from Google Maps.

The industry of the Russian Karelian type of tools (including adzes, axes, gouges) viewed in this context provides additional arguments in support for such a hypothesis. It is characterized by: (1) the preparation of tools in specialized workshops, not permanent settlement sites, (2) using of high-quality raw material (at least 6 on the Mohs scale of mineral hardness, mostly metatuff), (3) using of complicated flaking technique and high-quality technique of abrasion, (4) the high quality of the majority of complete artefacts, (5) big morphological standardization of finished products. These features, which were not characteristic for wood-chopping implements in Karelia dated to earlier periods, enable suggesting the existence of production specialization (Tarasov 2008). The finds of RussianKarelian type tools in places located at great distances from the only one production centre known at the moment - in the outfall of Shuya River on the western coast of Onega Lake (Figure 1) enable proposing that substantial amount of tools were made for the exchange (Tarasov 2008; Kriiska et al. 2011). 

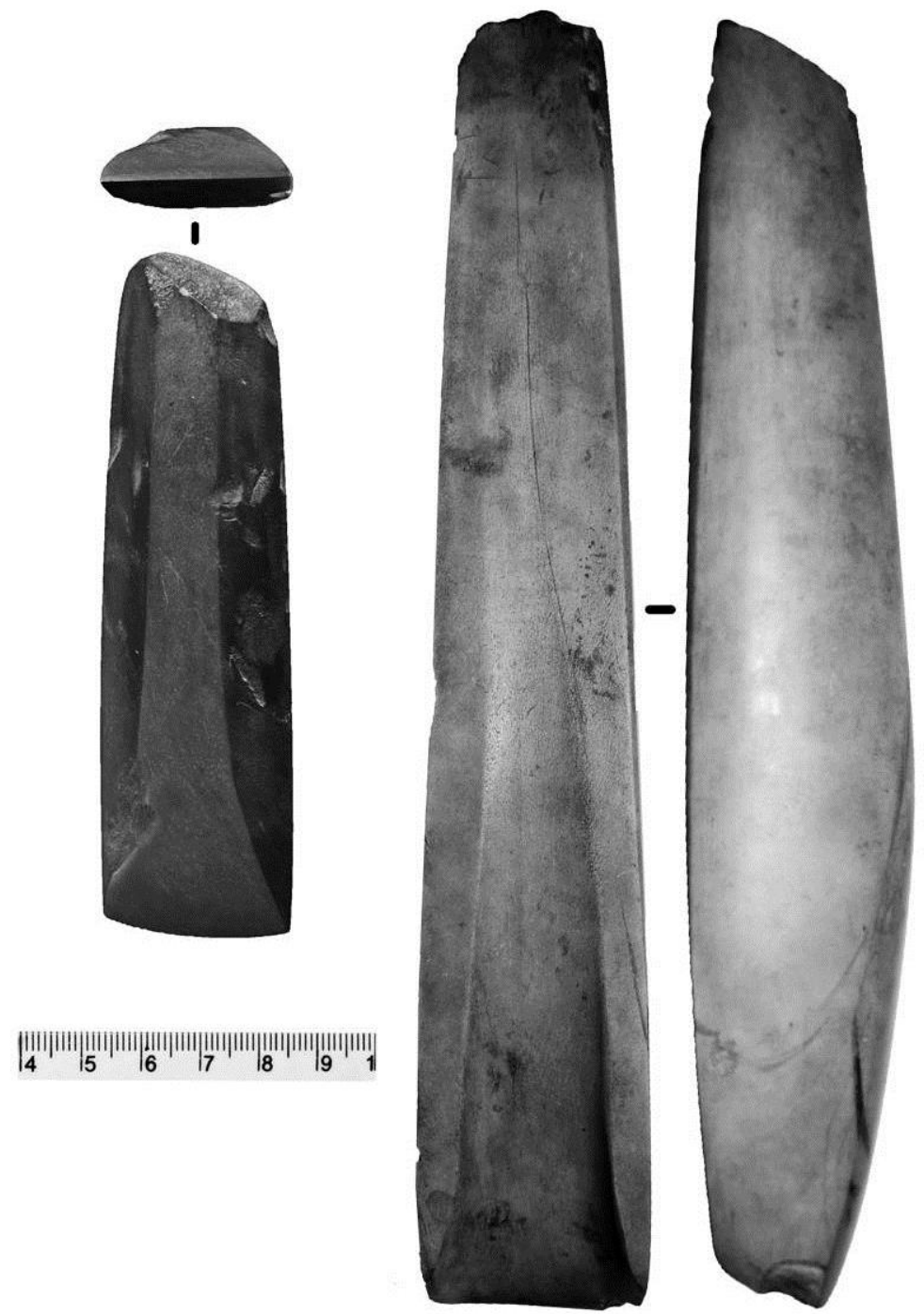

Figure 2. Typical tools of the Russian Karelian type (metatuff). 1 - adze (Karelia, Fofanovo XIII workshop site, preserved in ILLH KRC of RAS, Petrozavodsk), 2 - gouge (Estonia, Aesoo, stray find, preserved in Institute of History in Tallinn). Photo by A. Tarasov, A. Kriiska
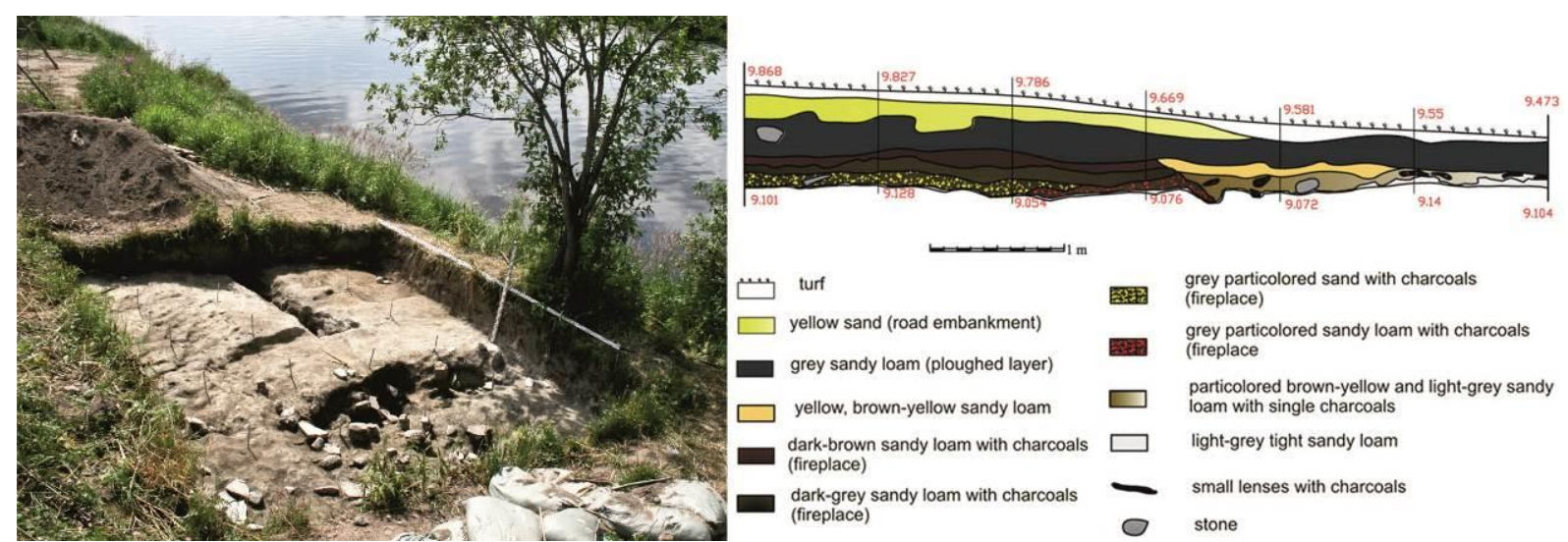

Figure 3. Trench on the workshop site Fofanovo XIII. Bottom of the cultural layer (north-east view) and eastern profile

In 2010 - 2011, excavations were carried out in one of the workshop sites - Fofanovo XIII (Tarasov 2011b; 2012). Cultural layer of ca. $0.5-0.9 \mathrm{~m}$ of depth was excavated in 30 
$\mathrm{m}^{2}$. (See Figure 3.) Excavations provided an extremely large artefact assemblage, consisting of 355542 finds. The assemblage is very rich and diverse. Besides production waste from making chopping tools it includes also waste materials from production of bifacial projectile points and polished slate points, ceramics, amber pendants, pieces of native copper, unburnt bones (mostly fish bones), etc. However, the absolute majority is built up by the waste flakes from making adzes, axes and gouges (296829 in total). There were also 684 discarded preforms of chopping tools. (See Figure 4.)
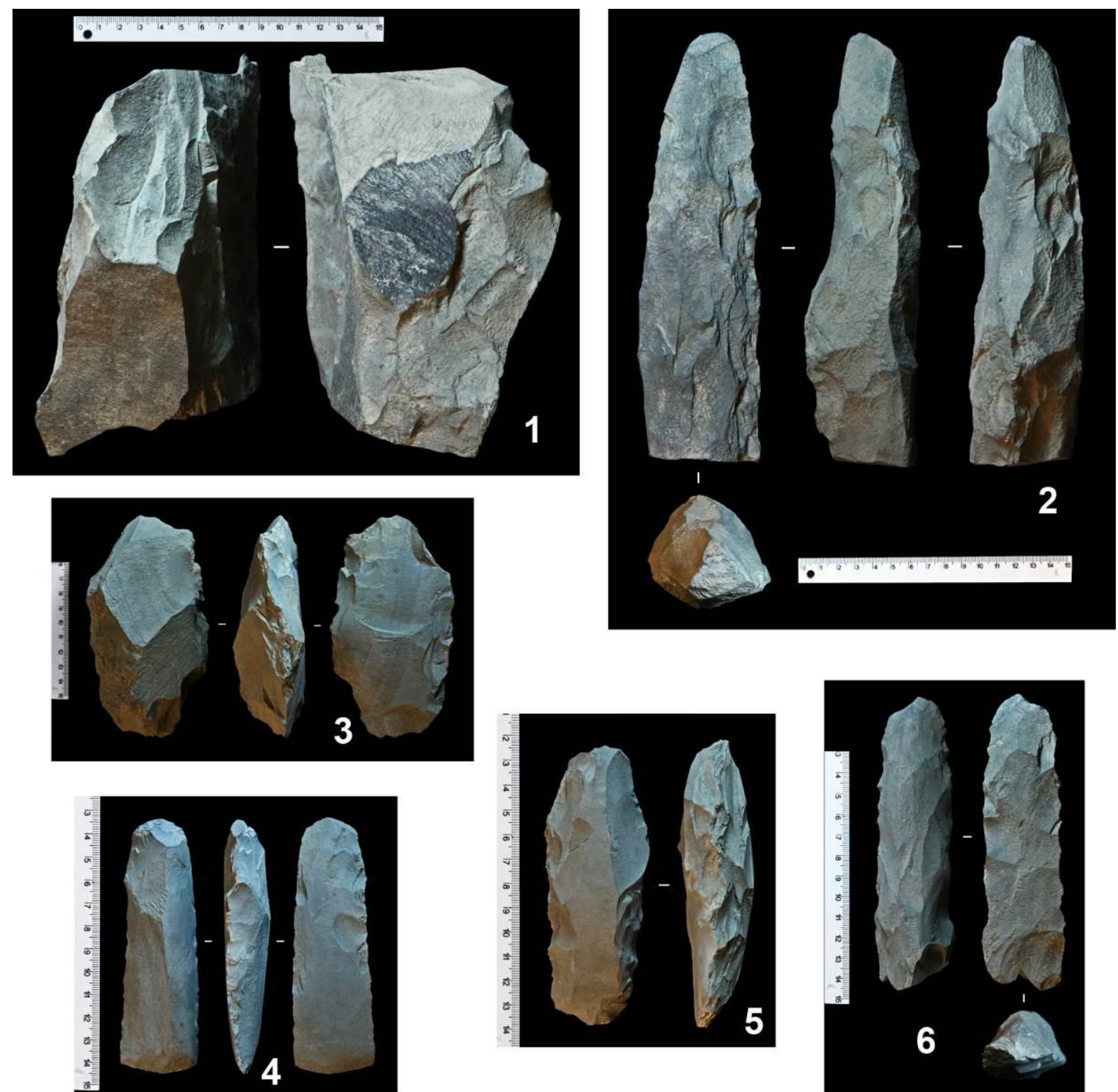

Figure 4. Discarded preforms of chopping tools from Fofanovo XIII assemblage (metatuff). $1-1$ st stage preform, 2-3,5 - 2nd stage preforms, 6 - 3d stage preform, 4-4th stage preform (stage of abrasive working)

The site provided numerous samples for radiocarbon dating. 5 dates have been prepared so far (See Table 1). The time span outlined by these dates is too long and does not correspond to the radiocarbon-based chronology of the varieties of Asbestos Ware that were found in the excavated area. Over 40 radiocarbon dates from sites with these varieties in Finland and Karelia place the time span of their existence between ca. 4800 - 3900 BP (3600 -2600 cal. BC), which is much less than the diapason of the charcoal dates from Fofanovo XIII (Zhulnikov et al. 2012 and references cited). Moreover, typological analysis indicates that the ceramic assemblage represents a transitional phase from one variety (Vojnavolok) to 
another one (Orovnavolok) according to the typology developed by A.M. Zhulnikov (1999). This transitional phase hardly could have taken more than 200 - 300 years (Zhulnikov A.M., oral communication). The only one AMS date made of charred crust on ceramics fits quite well into the expected time period, even if it might be slightly older due to the "reservoir effect" (Zhulnikov et al. 2012). As the charcoal samples from an open context are vulnerable to contamination by organic substances in the soil, it is more likely that the dates obtained from them deviate substantially from the real period of site's occupation. At the moment, the most likely dating can be proposed at around $3000 \mathrm{cal}$. BC, but we need more dates, especially ceramic crust dates to prove this. Duration of occupation cannot be estimated basing on the available radiocarbon dates.

Table 1. Radiocarbon dates from Fofanovo XIII workshop site. (Atmospheric data from Reimer et al. 2004; OxCal v3.10 Bronk Ramsey 2005).

\begin{tabular}{|c|c|c|c|c|}
\hline $\begin{array}{l}\text { Laboratory } \\
\text { index }\end{array}$ & Date $(B P \pm 1 \sigma)$ & Calibrated date $2 \sigma(\mathrm{BC})$ & $\delta$ 13C & Material \\
\hline Hela-2812 & $4454 \pm 42 \mathrm{BP}$ & 3340 - 2935 BC (95.4 \%) & $-27.5 \%$ & $\begin{array}{c}\text { charred } \\
\text { crust }\end{array}$ \\
\hline $\mathrm{SPb}-781$ & $3288 \pm 70 \mathrm{BP}$ & $1740-1420$ ВС (95.4 \%) & $-25 \%$ & charcoal \\
\hline $\mathrm{SPb}-782$ & $3158 \pm 80 \mathrm{BP}$ & $\begin{array}{c}1630-1250 \mathrm{BC}(94.1 \%) \\
1240-1210 \mathrm{BC}(1.3 \%)\end{array}$ & $-25 \%$ & charcoal \\
\hline $\mathrm{SPb}-783$ & $5150 \pm 80 \mathrm{BP}$ & $4250-3700$ BC (95.4 \%) & $-25 \%$ & charcoal \\
\hline $\mathrm{SPb}-784$ & $5220 \pm 80 \mathrm{BP}$ & $\begin{array}{c}4260-3910 \mathrm{BC}(88.6 \%) \\
3880-3800 \mathrm{BC}(7.8 \%)\end{array}$ & $-25 \%$ & charcoal \\
\hline
\end{tabular}

The workshop site Fofanovo XIII is unprecedented for Karelian archaeology and opens numerous directions of investigation. In this paper we will concentrate on just one issue estimation of the possible amount of finished chopping implements that were produced within the excavated area and transported away from the site to be used somewhere else. The estimation is based on experimental data obtained during a specially designed set of controlled replication experiments.

\subsection{Previous research}

The tools of the Russian Karelian (or Eastern Karelian) type, which are distinguished by their high quality and strict geometrical shape with trapezoid or oval cross-section have been under the attention of mostly Finnish and Karelian researchers already since the $2^{\text {nd }}$ half of the $19^{\text {th }}$ century. Due to investigations by Finnish archaeologists J. R. Aspelin, L. V. Pääkkönen, J. Ailio, A. Äyräpää this type was recognized as a specific Karelian feature, which, though, spread far away from the Karelian territory. Finnish researchers located the production centre on the western coast of Onega Lake in the outfall of Shuya River and discovered that some products from this centre were transported to distant areas, mainly to Finland and Estonia (Äyräpää 1944; Heikkurinen 1980; Nordquist \& Seitsonen 2008; Kriiska et al. 2013). Russian archaeologists of the Soviet period who studied Karelia were more or less aware about interpretation of these materials proposed by their Finnish colleagues, though in Russia it was not universally accepted (Bryusov 1947; 1952: 103-106; Foss 1952: 196; Clark 1953: 246247; Filatova 1971; Gurina 1974).

In the 1980s-1990s, A. M. Zhulnikov (1999) studied in Karelia a row of sites that, according to Karelian periodization of prehistory, can be dated to the Eneolithic. The pottery found from these sites is characterized by the use of organic material and asbestos for tempering (Asbestos Ware). It became clear that the tools of Russian-Karelian type are very common among the finds gathered from these sites, at the same time they are missing in the 
sites of other archaeological cultures in Karelia (Tarasov 2008). Zhulnikov's investigations clarified dating of this industry.

In the period following the Second World War Karelian archaeologists did not pay much attention to the outfall of Shuya River and the workshops located there were not even surveyed. Sporadic fieldworks resumed only in 1980s, while regular investigations, mostly surveying and collection of loose finds, started in the 1990s (Zhulnikov \& Spiridonov 2003: 21-22). In 2000, first excavations of a workshop site in this area-Fofanovo XIV were conducted by A.M. Zhulnikov. $400 \mathrm{~m}^{2}$ were excavated and provided ca. 9487 finds, mostly production debitage, but excavations were conducted with shovels and without sieving of the removed soil, and because of it these statistics ar not fully reliable. (See Table 2.) The results of excavations were partially published (Tarasov 2003). In 2010-2011, the workshop site Fofanovo XIII was excavated and provided enormously rich materials which form the basement for the current article.

Table 2. Number of finds from excavated workshop sites in the outfall of Shuya River

\begin{tabular}{cccccc}
\hline site & Fofanovo XIII & Fofanovo XIV & Shuya XXI & Shuya XXV & Nizovie I \\
\hline total area, $\mathrm{m}^{2}$ & 3500 & 40000 & 6500 & 1200 & 4700 \\
excavated area, $\mathrm{m}^{2}$ & 400 & 30 & 6 & 6 & 6 \\
finds, total & 9917 & 355542 & 610 & 1183 & 2885 \\
chopping tool preforms & 43 & 684 & 0 & 3 & 21 \\
$\begin{array}{c}\text { waste flakes from making } \\
\text { chopping tools }\end{array}$ & 9487 & 296829 & 402 & 1059 & 2467 \\
\hline
\end{tabular}

Mapping of the finds of the Russian Karelian type was resumed in 2008 when archaeological collections in Estonia were studied (Kriiska et al. 2013). The work continued in 2009 in Latvia (Kriiska \& Tarasov 2011). Since then, collections of a number of museums in Karelia and other regions in Russia were studied as well. At the moment, the data base contains descriptions of 3466 objects, including tools of this type and their fragments along with preforms. The latter mostly originate from the outfall of Shuya River and none of them was found outside of Onega Lake basin.

The raw material for making artefacts of the Russian Karelian type was identified in the $2^{\text {nd }}$ decade of the $20^{\text {th }}$ century by Finnish geologist E. Mäkinen. The researcher completed the petrographical analysis, which indicated that the majority of these wood-chopping tools have been produced of tuff, which is exposed on the north-western shore of Lake Onega, but has been carried more south from the lake by continental glacier (Äyräpää 1944). Due to its colour and slaty cleavage the material has been erroneously named the green slate of Aunus, Olonetz, Äänisjärvi or Onega in archaeological literature (e.g. Tallgren 1922: 67; Äyräpää 1944; Heikkurinen 1980: 5), however, we are dealing with a volcanic, not a sedimentary rock. Petrographic investigation resumed in 2009, when petrographic analysis of the finds from Estonian territory was conducted. The study confirmed that the majority of the analyzed sampling was made of metatuff that is absent in Estonia but is fully analogous to the material of samples from the western coast of Onega Lake (Tarasov et al. 2010).

\section{Design of experiments}

\subsection{Quantitative estimations of the output of lithic production in the archaeological literature}

Quantitative estimations do not seem to be very common in the literature. However, they are not totally unusual for the lithic research. Usually these studies deal with quite late industries, beginning since the Neolithic, and with situations that allow suspecting some sort of specialized and "mass-production". They aim at confirming, correcting or disproving these 
claims (Le Roux 1979; Torrence 1984; Shafer \& Hester 1986; 1991; Mallory 1986; Sundström \& Apel 1998; Sundström 2003: 258-259; Petrequin et al. 1998; Pelegrin 2002; Whittaker et al. 2009; Barzilai 2010: 16-19). Most of them in one way or another use technological assessment of the corresponding technology, usually supplemented by controlled experiments.

In the case of axe production two basic approaches have been suggested. One focuses on calculation of the volume of rock that has been extracted from quarries and deposited in the workshops (Le Roux 1979; Petrequin et al. 1998). C-T. Le Roux (1979) estimates the amount of tools produced in an area basing on the volume of an average axe. The other approach mainly considers the amount of waste flakes that can be produced by manufacturing an average axe, and pays close attention to peculiarities of concrete technologies (Shafer \& Hester 1986, 1991; Sundström \& Apel 1998; Sundström 2003: 258-259; Whittaker et al. 2009). Experimental replication can be of great help for understanding these peculiarities. In the study by H.J. Shafer and T.R. Hester $(1986 ; 1991)$ the calculations were performed basing on just one diagnostic type of flake, because in the technology studied by them this sort of a flake was detached just once from every preform. The amount of final products is thus equal to the amount of flakes of this diagnostic type.

In our opinion, when we try to estimate the absolute number of finished products that were made in a given workshop, the second approach is more relevant, since it takes into account unique technological characteristics.

\subsection{Technology of making the tools of the Russian Karelian type}

Metatuff, which is the most common raw material for producing implements of this type, despite its ability to fracture conchoidally, is still very difficult for knapping and requires application of a very big force. Impossibility to create any fracture and detach new flakes appears in the case of this material much more often than in the case of flint, chert, obsidian, etc. The Russian Karelian technology can be seen as a compromise between the necessity to create strict geometric shape and attempts to minimize loss of raw material and efforts.

Strict geometric and very standardized shape with trapezoid, half-oval or, in rare cases, parallelogram cross-section was definitely an important feature for the ancient manufacturers and can be regarded as a real value. Achieving strict shape just by knapping was accomplished with the use of indirect percussion with antler punches, which provides very high degree of controlling placement of blows as well as possibility to concentrate the full strength of a blow in the proper direction. Despite its advantages, the use of this technique is possible only with properly prepared blanks. The preforms must have angular shape with planes attached to each other by not too obtuse angles, though sometimes the angle can be bigger than $90^{\circ}$. According to our experience, in very rare cases it is possible to create such a preform out of a whole boulder with initially rounded surfaces, which would not be a problem with better knappable materials. Therefore, as can be seen from analysis of abandoned preforms originating from the workshop sites, more often masters preferred big flakes (sometimes close to $150 \mathrm{~mm}$ of length) that initially had proper faces and proper angles at least at the contact of ventral and dorsal surfaces, and angular pieces detached from a bedrock.

Indirect percussion was used similarly to the technology of making 4-sided axes (see Figure 5) that are characteristic for a number of European cultures, especially Funnel Beaker (Hansen \& Madsen 1983; Madsen 1984), but in the Russian Karelian industry masters achieved with the aid of this technique trapezoid cross-section of tools instead of rectangular cross-section. (See Figure 4.) Of course, determining of the knapping technique in far too many cases is not unequivocal. However, indirect percussion can be quite safely recognized if we see concave platforms (Pelegrin 2004). Any direct percussors would not be able to reach 
the platform and would be stopped by the ridges surrounding it, thus spoiling the impulse. Diagnostic features of the debitage and preforms resulting from the use of punch technique in this technological context are shown in Figure 4. It should be mentioned also that excavations in Fofanovo XIII provided a number of fragments of antlers. The state of preservation is poor and a use-wear study is not possible, but interpretation them as punches seems the most probable one.
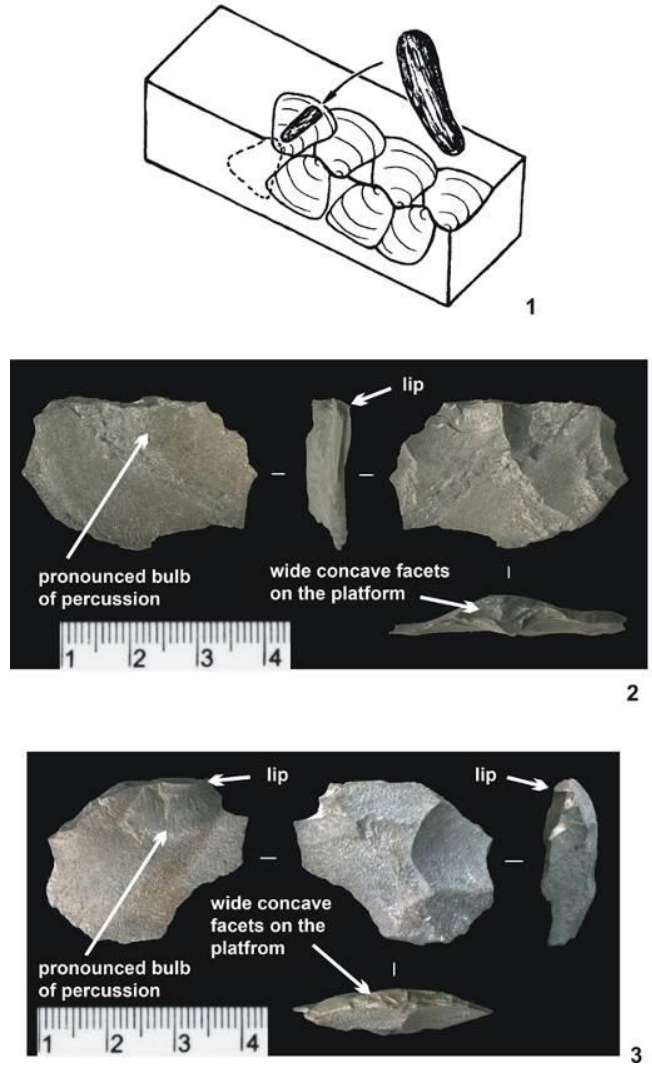
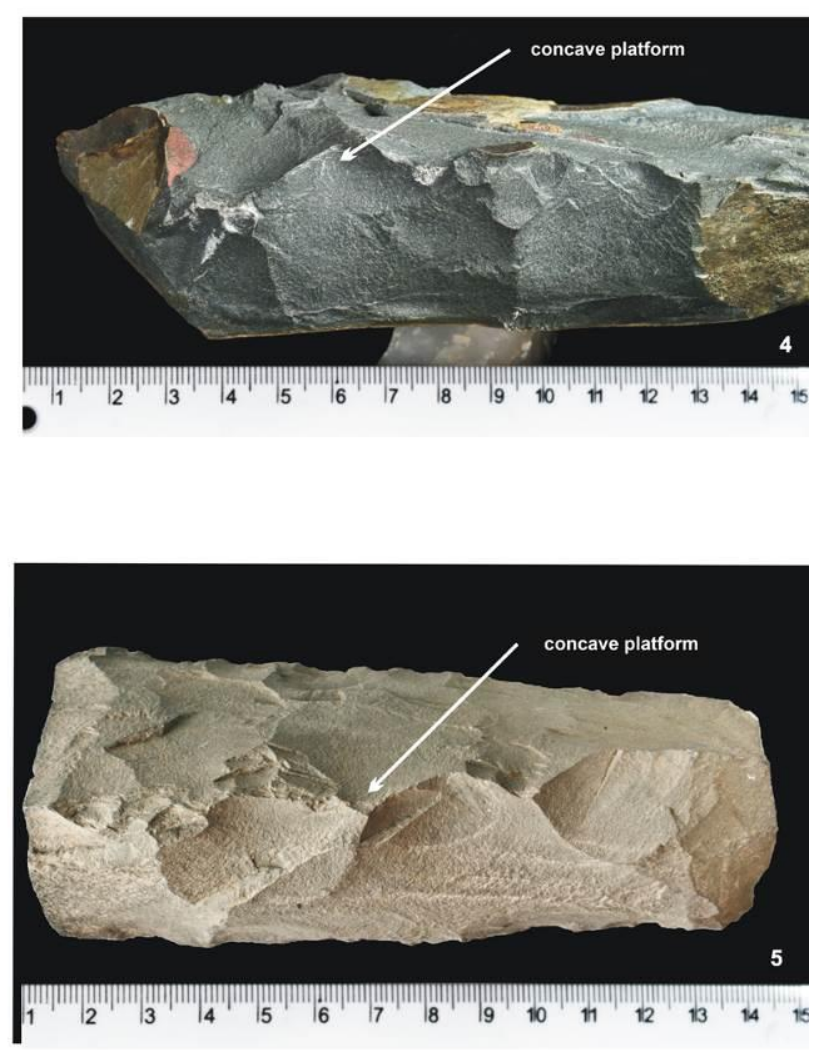

Figure 5. Technology of Russian Karelian tools. Punch technique and features of debitage resulting from its use. 1 - the method of using punch technique, 2 - an experimental flake, 3 - a flake from Fofanovo 13 assemblage, 4 - an experimental preform, 5 - a preform from Fofanovo 13 assemblage. 2-5 - metatuff

The reduction sequence can be divided into several stages. (See Figure 6.) We distinguish three stages of knapping that are followed by the stage of grinding and polishing. The difference between the first and the second stages is quite obvious because here we switch from direct to indirect percussion. Distinguishing of the third stage is probably not unequivocal, but we consider it as a separate one because of more regular application of indirect percussion which is close to "patterned flaking".

\subsection{Experimental replication of the technology and testing its relevance}

In order to obtain comparative sampling of waste products a series of replicating experiments was conducted. The raw material was taken from a closest deposit of metatuff where extraction of nodules is possible without special facilities. The pieces of raw material included both bedrock nodules and boulders from the adjacent lake shore. In total, 31 experiments were conducted, that is, 31 pieces of raw material were knapped until making a final product or exhausting any possibilities to transform it into the desired shape. Big flake, if it was used for a blank, was considered as a separate piece (and a separate experiment). If a piece was broken in the very beginning, and more than one resulting piece was still usable, 
processing of one of them was considered as the same experiment, while others were recorded as new ones. Flakes from different reduction stages were collected separately. After collecting, they were sieved through a $4 \mathrm{~mm}$ metal sieve in order to clean them from the smallest uncountable particles.

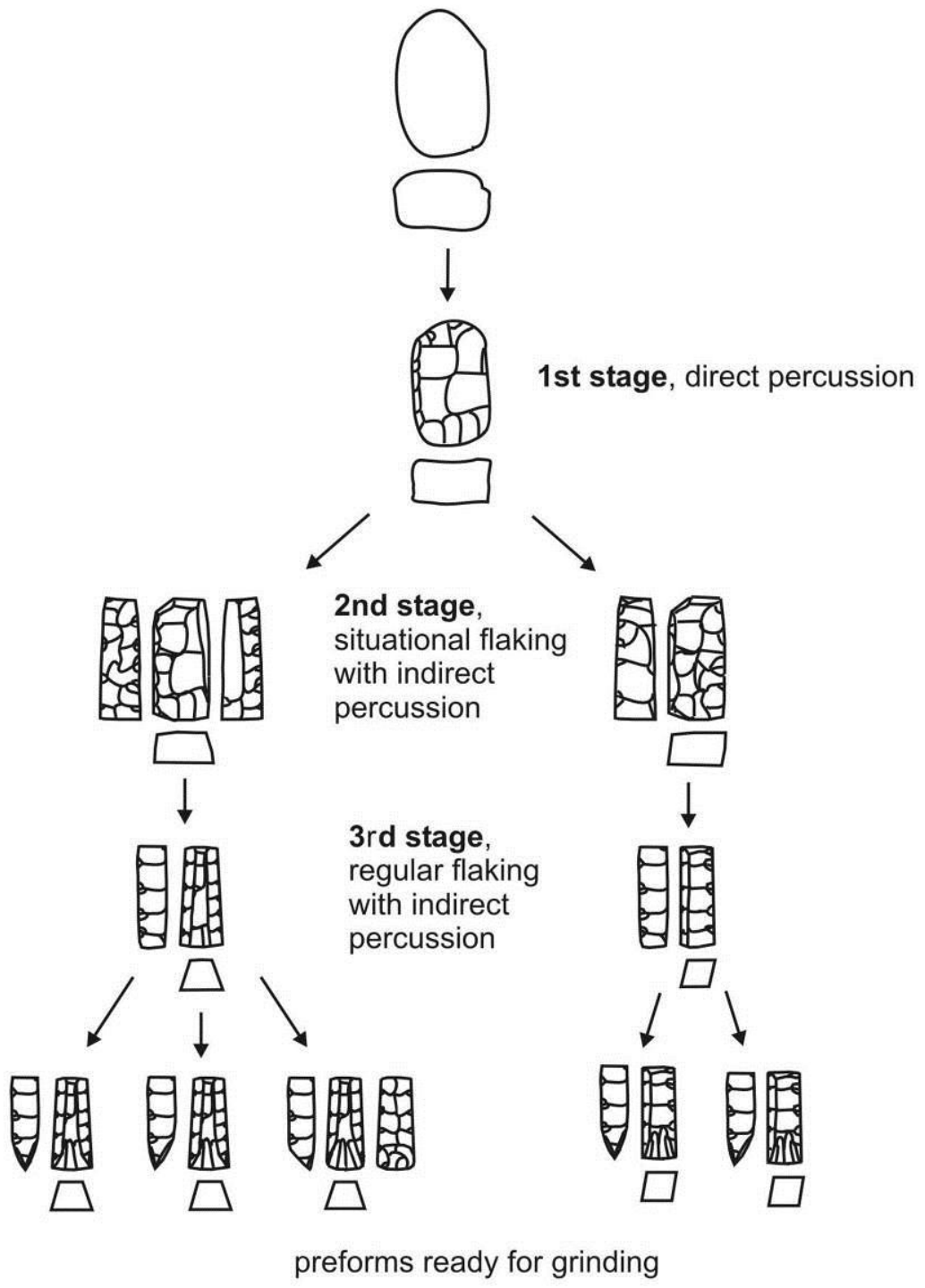

Figure 6. Technology of Russian Karelian tools, simplified reduction sequence

The experimental series resulted in 11 complete tools (Figure 7), i.e. preforms ready for grinding, 43 abandoned preforms that could not be transformed into tools and 17524 waste flakes. The amount of complete tools and abandoned preforms outnumbers the amount of experiments because the majority of experiments, due to breakages, resulted in more than one piece of knapped stone, either an abandoned preform or a tool.

As can be seen in Figure 5, the main distinctive traits of experimental products are fully analogous to those of ancient artefacts. Besides these qualitative proofs of the relevance of experiments, we also conducted some quantitative evaluations. Measuring and counting was simply accomplished in the case of tools and preforms, since their amount in both excavation and experimental samplings was not extremely big. But hundreds of thousands of flakes posed quite a serious problem, since it was practically impossible to deal with each of them individually. Mass-analysis, which is also called aggregate analysis (Andrefsky 1998: 126134 and references cited; Odell 2004: 130-132 and references cited), was used instead. 


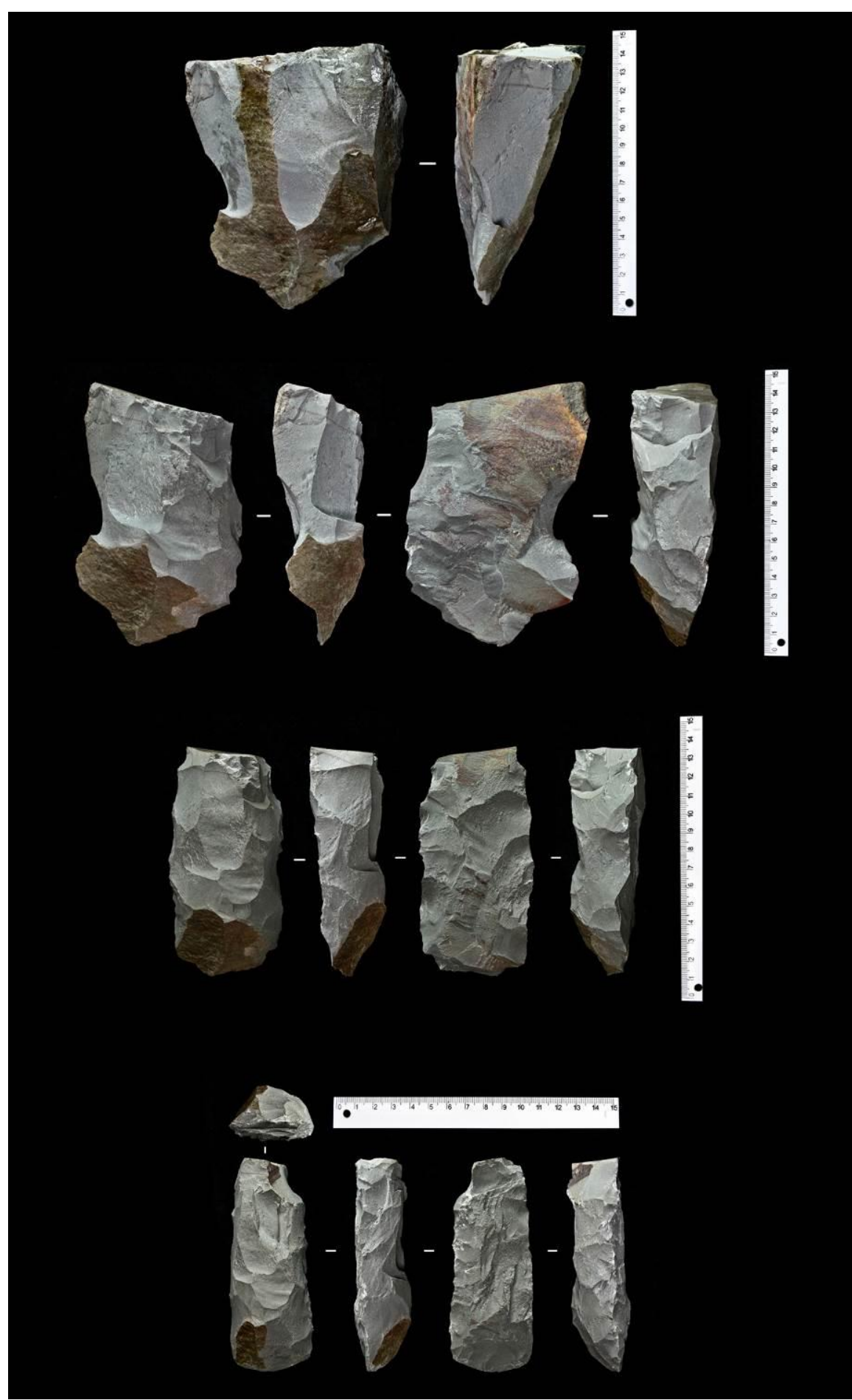

Figure 7. Experimental modelling of the Russian Karelian technology, reduction sequence of making an adze (metatuff)

Mass-analysis was performed with the aid of an image recognition program Scion Image. Until 2011, it was possible to download it from the developer's website, but at the moment, unfortunately, the company has shut down. The analysis consisted in mass-photographing of flakes and processing images in a personal computer with this program and a specially designed macro, which was created using embedded programming language (Tarasov \& Zobkov 2013). The end result of the analysis was a spreadsheet containing information about the amount of flakes in the pictures and their size, i.e. the length along the longest axis. 


\section{Length of complete tools}

The amount of waste flakes needed for producing one tool can depend on the size of a given tool, which more often than not has a positive correlation with the size of the initial piece of the raw material. Figure 8 demonstrates length distribution of the complete tools of the Russian Karelian type that were found in all possible contexts. The graph uses only the data for non-broken specimens that do not have visible signs of repair and thus quite likely have not been shortened after breakages. As it can be seen, the length of these tools varies a lot, and short specimens are very common, as well as items exceeding $100 \mathrm{~mm}$ and $150 \mathrm{~mm}$. Items exceeding $200 \mathrm{~mm}$ are present. The knapping skill of one of the author of this article responsible for the experiments (A. Tarasov) was not enough for producing really long implements. However, the difference between the mean length of finished tools in the experimental set and the mean length of tools from ancient contexts is not statistically significant. (See Figure 8.) It is interesting to note, that the distribution of length of tools (in logarithmic scale) is close to normal distribution.

\section{Consistency in conducting experiments}

Distribution of lengths of flakes from experiments is shown in Figure 9. We did not include graphs presenting each experiment in order to save space, but it is worth mentioning that the distribution patterns in all cases are very much similar. Consistency in these distributions assures that experiments were conducted consistently as well. At the same time, it is rather surprising that the distribution pattern in successful experiments, i.e. those that resulted in a finished tool, does not differ much from the pattern of unsuccessful experiments. In samplings from unsuccessful experiments the flakes from later stages of reduction sequence are underrepresented. However, composition of size classes of flakes remains generally the same at every stage, but just the number of smallest flakes is slightly higher at the $3 \mathrm{~d}$ stage than at the earlier stages, and the longest flakes disappear the closer we are towards the final product (Figure 10).

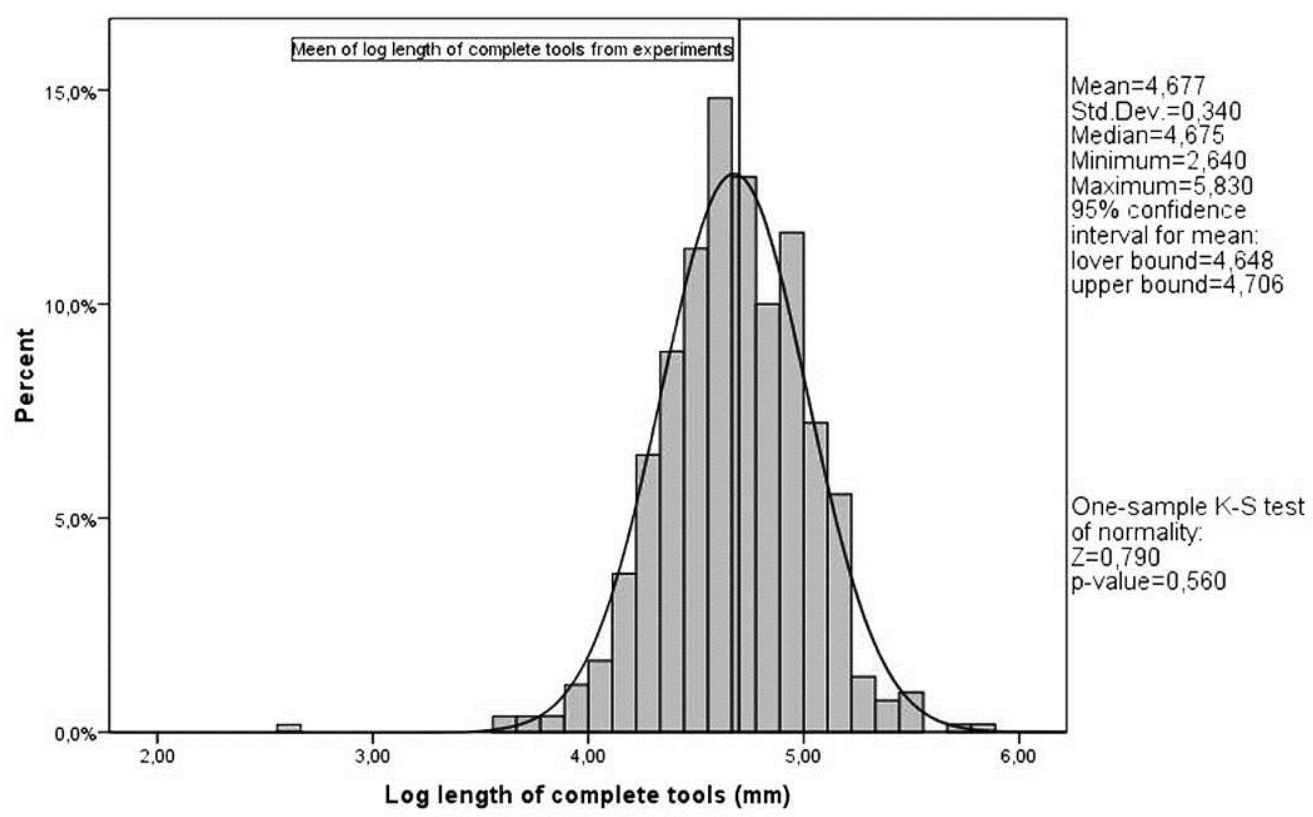

Figure 8. Distribution of length of ancient tools of the Russian Karelian type found in all possible contexts (logarithmic scaling) and results of one-sample Kolmogorov-Smirnov test (K-S test) of normality. Only complete tools without distinctive traces of repair are included 

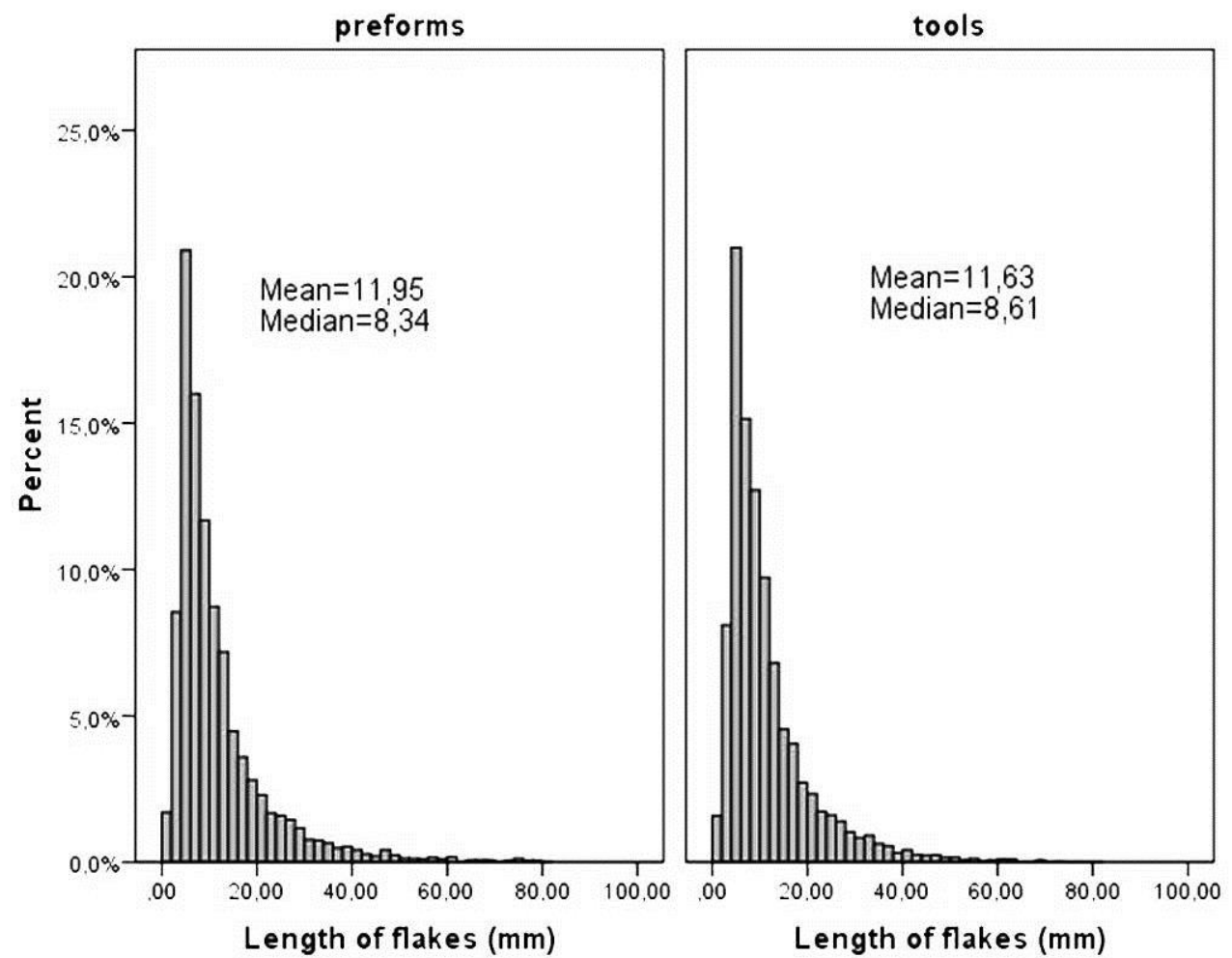

Figure 9. Comparison of flake length distributions in "successful" (resulting in a complete tool) and "failed" experiments. P-value of two-sample K-S test is 0,250

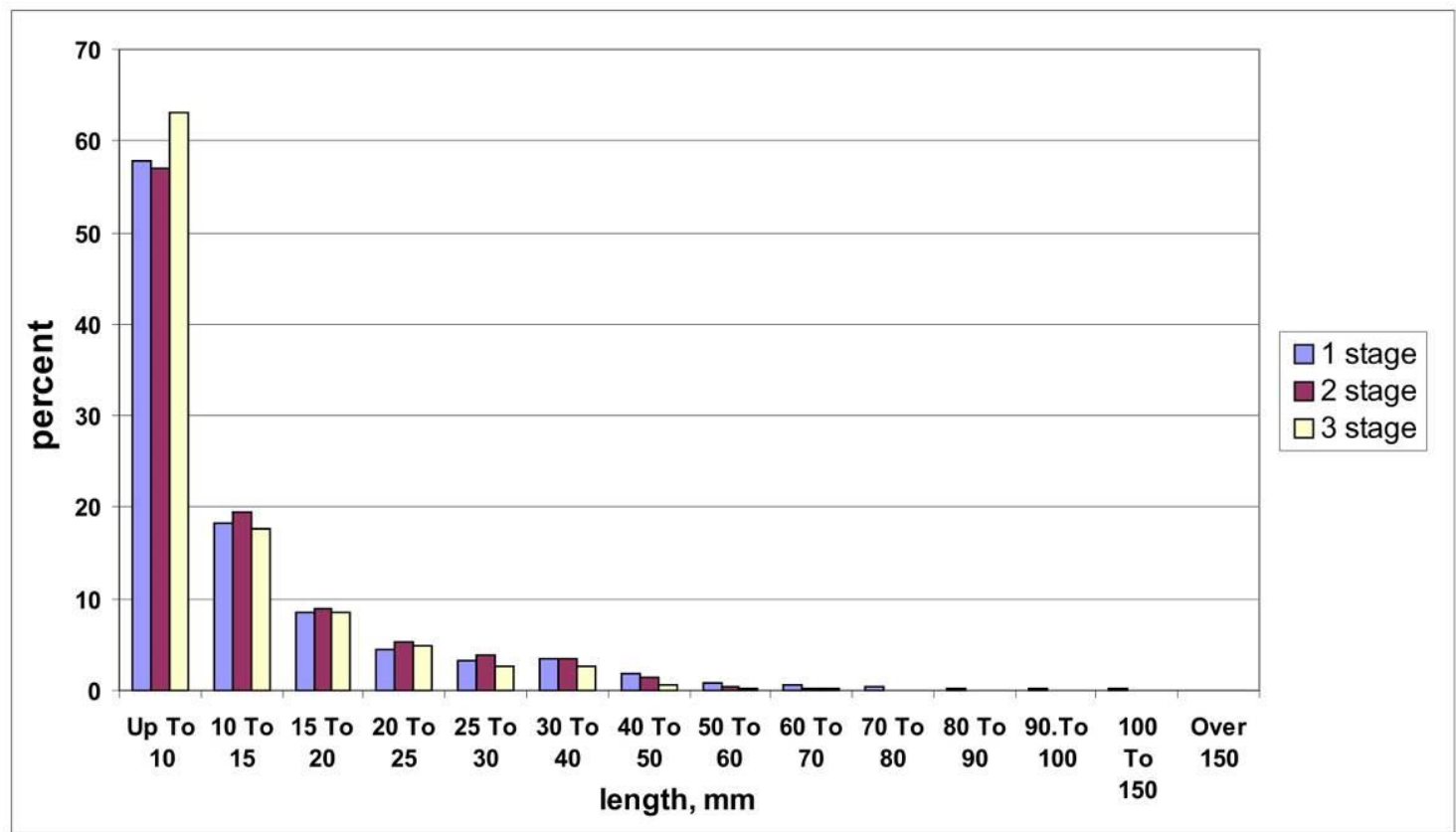

Figure 10. Distribution of size classes of experimental flakes belonging to different reduction stages

\section{Experimental flakes vs. flakes from excavations}

Needless to say, only metatuff flakes from the excavations, which are by-products of making axes and adzes and not other types of tools, are used for the comparison. (See Figure 11.) The distributions are very much similar in the right and central part of the graphs, but differ considerably in left part, which is built up by the smallest flakes. The experimental sampling contains much more shatter than the assemblage from excavations. 

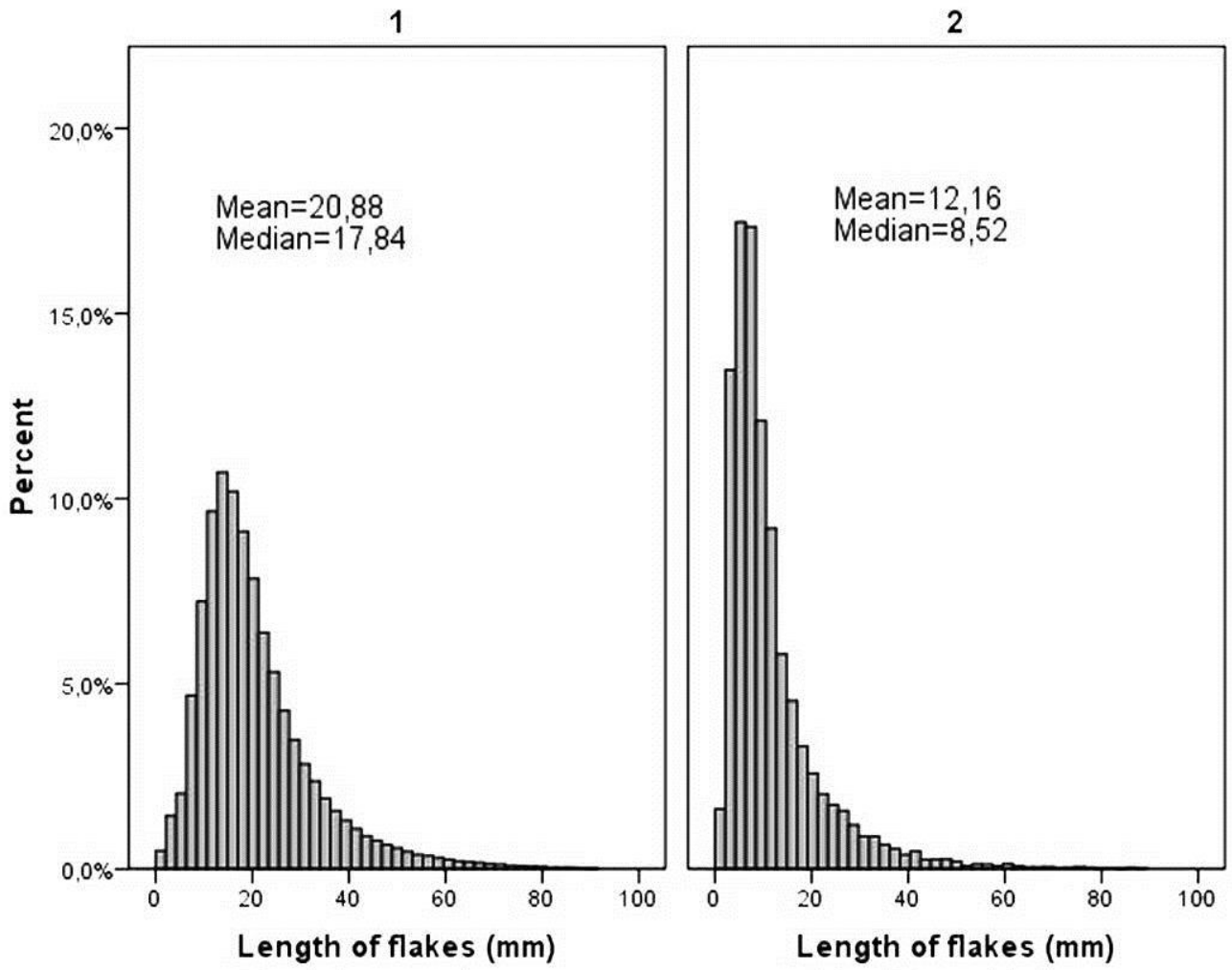

Figure 11. Comparison of flake length distributions in the Fofanovo XIII assemblage and the experimental assemblage. 1 - assemblage from excavations, 2 - experimental assemblage

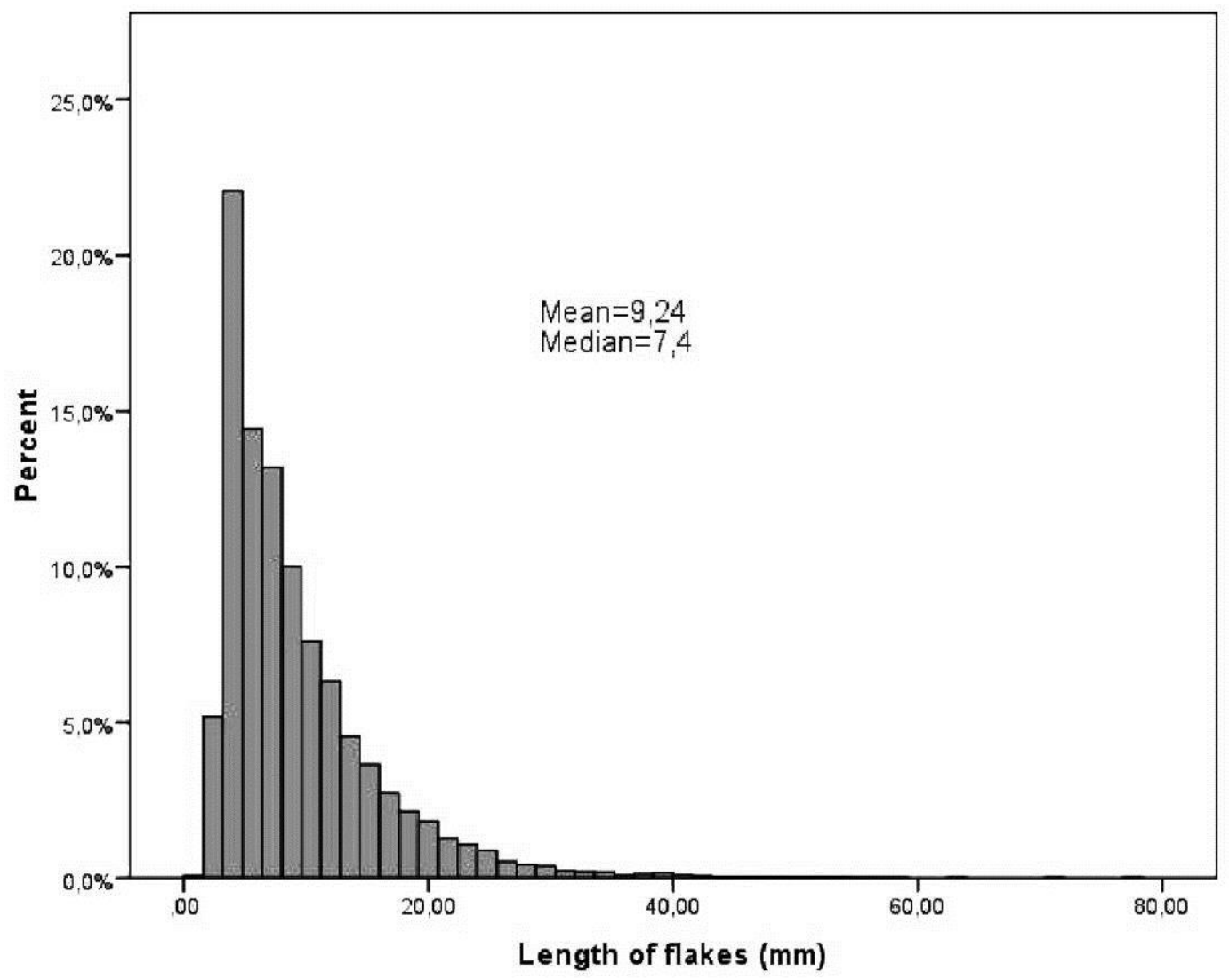

Figure 12. Flake length distribution in Derevyannoye XVIII assemblage 
In our opinion, the most probable explanation of this difference lies in the excavation procedure. The excavations were performed with sieving of the removed soil. However, the necessity to gather from each sieve hundreds and thousands of flakes of different sizes definitely blunts the eyes, and lots of smallest flakes remain in the dust that is finally thrown away. The situation is even more complicated by the type of the soil. Unlike in the majority of Karelian sites, the soil in Fofanovo XIII is very sticky sandy loam, which covers flakes like a plaster. Bigger flakes are still recognizable, but in the case of smallest ones what looks like a small ball of soil may be in fact a piece of shutter covered by soil.

This assumption is supported by results of 2013 excavations of another knapping floor $\left(18 \mathrm{~m}^{2}\right)$ containing debitage from making Russian-Karelian tools on the site Derevyannoye XVIII. It is located in ca. $40 \mathrm{~km}$ to the south from the main production centre. The excavations were conducted in very good conditions, much more favourable for collecting the smallest finds. First, the soil is dry fine-grained sand without any stone particles. Second, this soil was sieved through the mesh in much smaller volumes, not more than a $10 \times 10 \times 5 \mathrm{~cm}$ block was processed at once. Distribution of flakes' length in this assemblage is very much similar to that of the experimental sampling. (See Figure 12.) The mean value is even less than in the experiments and testifies that only the last stage of reduction was taking place in this floor. This example shows that when the excavation conditions are really good for collecting very small artefacts, the amount of microdebitage, which is the result of implementing the Russian Karelian technology in the ancient times, is not less than in experimental modelling of this technology.

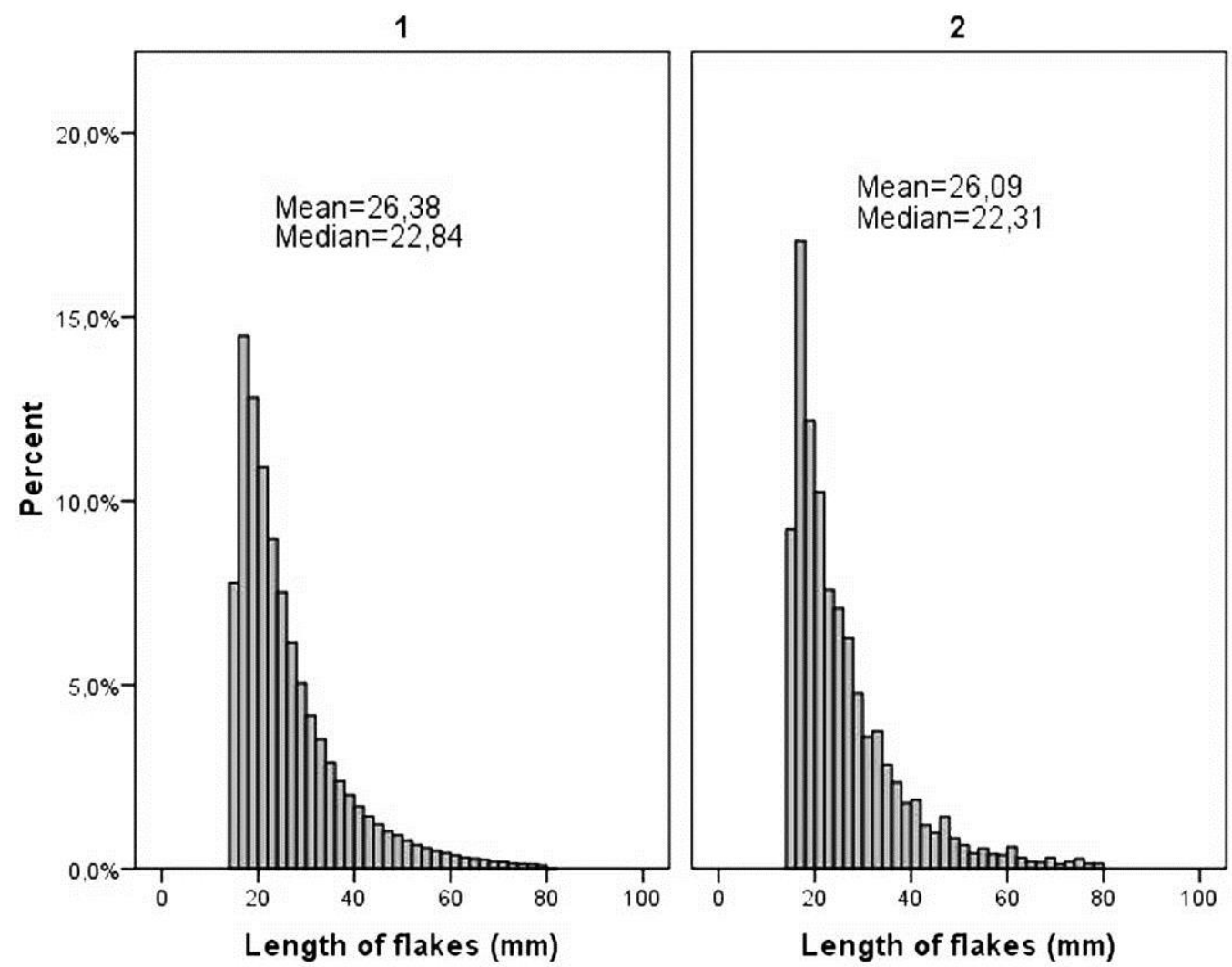

Figure 13. Comparison of flake length distributions (only flakes $>15 \mathrm{~mm}$ ) in the Fofanovo 13 assemblage and the experimental assemblage. P-value of two-sample K-S test is 0,113

Therefore, in order to make samples comparable, we decided to exclude the smallest flakes from both assemblages and chose an arbitrary border value of $15 \mathrm{~mm}$. What is important, by doing this we did not create a situation when one of the stages gets dramatically 
underrepresented, because amount of different size classes of flakes at every stage of reduction in the experimental series remains more or less equal. (See Figure 10.)

After exclusion of flakes less than $15 \mathrm{~mm}$ the distributions look almost identical. (See Figure 13.) Similarity between two samplings assures us that the use of experimental data is relevant in this particular case. First, it means that the processes reflected in the assemblage from the excavated site and modelled during experiments were generally similar. Second, all the reduction stages, most likely, are present in the excavated assemblage, which is supported also by the presence of preforms abandoned at different stages.

\section{Estimation of the scale of production}

The estimation is made only for the excavated part of the site $\left(30 \mathrm{~m}^{2}\right)$. We do not have reliable data for the rest of the site's area, which is ca. $40000 \mathrm{~m}^{2}$. Rules of conducting archaeological fieldworks in Russian Federation do not allow excavating numerous tiny patches of the cultural layer as it was done in some projects already referenced here (Shafer \& Hester 1991; Whittaker et al. 2009), while organizing excavations of another $20-30 \mathrm{~m}^{2}$ providing, probably, comparably enormous amount of artefacts, is impossible for us at this moment. However, our estimation will definitely help to develop some imagination about the whole workshop.

Experimental replication provided data for estimating the possible range of the amount of waste flakes that can be left after production of an average axe or adze following the technology characteristic for the Russian Karelian tools. Of course, this amount can vary a lot from one specimen to another, but deviations from the experimental results cannot be extreme. We cannot produce such a tool after detaching just 10-30 flakes (bigger than 15 $\mathrm{mm}$ ), and we hardly can produce several thousand flakes just after making one axe. However, we cannot use these data for plain estimation of the production output in our site, because a great part of flakes was detached from preforms that were finally discarded.

Straightforward calculation of the amount of flakes needed for making an average preform is not possible due to several reasons. The preforms were abandoned at different stages of the reduction process. Most of them are broken, and it is not always possible to estimate whether any of them broke in two or three or even more pieces. The part of a broken preform that is missing could have been longer than the part that we have at hand and thus could have provided more flakes and vice versa. One part of a broken preform could have been finally transformed into a finished product, and thus all the resulting flakes can be considered as flakes from making a tool. Furthermore, the amount of flakes definitely depended on the size of the initial piece of raw material, which we do not know. This amount also depended on the skill and individual preferences of the masters who had been knapping at the site when it was used as a workshop.

Because of all these obstacles we decided to refuse from a straightforward evaluation and approach the problem from another side. The starting point in our approach is a countable value that is related to the level of skill-the "failure coefficient".

Among 31 experiments in the experimental series 11 resulted in finished preforms ready for grinding, and 20 failed (resulted in unfinished preforms). "Failure coefficient" in the experiment is 20/11 1.8. In other words, the percentage of spoilage is $20 / 31 \sim 0.65$ or $65 \%$. The experimental coefficient is rather high which is not surprising taking into account the properties of the raw material, which is very tough and has far too many internal cracks and impurities, and the fact that knapping is not our everyday activity.

The experimental "failure coefficient" can be used as the basic value along with the experimental data about the number of flakes (table 3) in successful and failed experiments (only the flakes bigger than $15 \mathrm{~mm}$ are considered here). The average amount of flakes 
resulting from making of $n$ tools can be calculated in the following way: $215 n+1.8 n 82=362.6 n$. Similarly, minimal and maximal amount of flakes can be expected to be $94 n+1.8 n 26=140.8 n$ and $374 n+1.8 n 223=775.4 n$.

Table 3. Number of flakes resulting from successful and failed attempts to make an experimental tool

\begin{tabular}{ccc}
\hline & successful attempts & failed attempts \\
\hline average & 215 & 82 \\
$\min$ & 94 & 26 \\
$\max$ & 374 & 223 \\
\hline
\end{tabular}

Now let's assume that the failure coefficient among the ancient masters was the same as in our experiments. If so, the average amount of tools produced within the excavated area can be calculated this way: 187667/362.6 518, where 187667 is the number of flakes bigger than $15 \mathrm{~mm}$ in the excavation assemblage. The minimal amount is calculated similarly and is $\sim 242$, the maximal amount- $\sim 1333$ tools.

Of course, we cannot be sure that the average skill of ancient knappers was just like our own. We can try to assess this difference by estimating expected amount of abandoned preforms with the experimental "failure coefficient", which can be done by the same calculations as those given above but with slight changes in the first formula. Average amount of flakes resulting from production of $n$ abandoned preforms is $215 n / 1.8+82=201.4$, and average amount of preforms from the excavated area of Fofanovo 13 workshop should be 187667/201.4 932 (maximal amount would be 2399 and minimal amount- 430). Since the actual number of preforms from excavations is a bit less than the expected average value (684), the real rate of failure in this area was probably less than in the experiments as well and amount of finished preforms was somewhat bigger than the estimated average value. Therefore, in our opinion, the most likely diapason can be estimated to be between 500 and 1000 finished tools.

The same method can be applied to our own experimental results. Average expected amount of finished tools from the experiments can be derived just as it has been done for the excavation assemblage: 4004/362.6 $=11.04$, where 4004 is the number of flakes bigger than $15 \mathrm{~mm}$ produced during the experiments. Here we see full coincidence with the actual reality - the number of finished experimental tools is 11. Average expected amount of preforms, however, is more than twice as less: 4004/201.4=19 (in reality 43). But this number, in fact, is the expected amount of unsuccessful attempts to produce a tool, because the "failure coefficient" is calculated using the number of attempts instead of the number of items resulting from these attempts. In most cases a failed attempt to produce a tool ended up in breaking the preform into two pieces, or two broken preforms; situations when we got just one non-broken abandoned preform or more than two broken preforms are more rare. Therefore, in order to get the expected number of preforms, we can double the result of previous calculation: $19 * 2=38$. This number is very close to the actual amount.

After this correction we can return to the assemblage from excavations. If the rate of failure of ancient masters was the same as in our experiments, than they could have produced ca. $932 * 2=1864$ abandoned preforms (average estimation). Because the real amount of preforms originating from the excavated area is much less (684), than it is more likely that the average skill of the manufacturers was even higher. Therefore, we believe that the number of finished tools was much closer to 1000 than to 500 items, and possibly even bigger than 1000 .

\section{Discussion}

If in just $30 \mathrm{~m}^{2}$ ancient masters produced several hundred tools, we can expect that the whole scale of production of this workshop was dozens of thousands or even hundreds of 
thousands of complete implements. At the moment we cannot reliably estimate duration of the use of the site, and it is still possible that it lasted for several hundred years. Nevertheless, axes and other chopping tools, which are quite massive, made of a tough material with considerable effort, perfectly polished, are not designed for very short period of use and can last for a considerable time, probably even exceeding one year. Therefore, even if not more than several hundreds of finished products were produced annually in just one site, in our opinion, it can be qualified as an evidence of specialized "mass-production", i.e. production greatly exceeding the needs of the manufacturers.

I should stress here that the evidences of full cycle of production of these tools have been found so far only in the outfall of Shuya River. Furthermore, none house depression has been found in the lower reaches of Shuya River so far. According to the data available after more than 100 years of investigation, outside of this centre only minor operations of finishing halfmade products were taking place in some sites on the coast of Onega Lake. At least in Onega Lake basin, the needs for chopping implements on the dwelling sites with Asbestos Ware were satisfied mostly by Russian Karelian tools (over $80 \%$ in the sites with single-period complexes), which were not produced anywhere outside of the outfall of Shuya River. Outside of Onega Lake basin any preforms are completely absent, while complete tools in some places and some sites located at the distances of $300-400 \mathrm{~km}$ are found in considerable series. These issues will be thoroughly discussed in another publication, which is currently being prepared.

Examples of even much more intensive production can be found in the archaeological literature. Maya lithic workshops in America contain some hundreds of thousands or even millions of waste flakes bigger than $3 \mathrm{~mm}$ per $1 \mathrm{~m}^{3}$ (Shafer \& Hester 1991; Whittaker et al. 2009). Similarly large volumes of waste flakes per cubic meter were encountered in some adze and axe making workshops in New Guinea (Bickler \& Turner 2002). Comparing to these cases, the Karelian case discussed in this paper does not look very impressive. However, the density of waste debitage is comparable to some other industries that have been also interpreted as industries of specialized production, such as blade manufacturing of the PrePottery Neolithic in the Near East (Barzilai 2010: 46-47). It is very unlikely that the density of hunter-gatherer population in Onega Lake basin in Karelia during the Eneolithic period was the same big as in the Maya agricultural lands. Much smaller scale of production on the western coast of Onega Lake must have been adequate and enough for the local population. It should be also mentioned that the number of finished tools in Fofanovo XIII was many times higher than in axe workshops in eastern central Sweden studied by L. Sundström (2003), which were interpreted as an evidence of domestic production rather than specialized craft production (Sundström 2003:251-261).

The scale of production in Fofanovo XIII workshop is unprecedented for Karelian archaeology and we do not know any other workshop whose cultural layer is similarly densely packed by production debitage (See, for example, Pesonen P.E.1982, 1984; Tarasov et al. 2007; Tarasov 2011). At the same time, other workshop sites from the outfall of Shuya River that have been excavated so far also contain much smaller amount of waste, than Fofanovo XIII. (See Table 2). However, they are concentrated in a very compact area, ca. $2 \times 2$ $\mathrm{km}$, and such a concentration of workshops is itself a unique phenomenon for the Karelian archaeology.

Discussing concrete forms of craft specialization that probably was developing in Karelia during the Eneolithic period is out of the scopes of this paper. We can only mention that allyear round engagement in this activity seems very improbable, considering both the scale of production and the lack of remains of long-term dwellings in the outfall of Shuya River. More likely, we deal with some sort of seasonal activity and part-time specialists. 
Another aspect of the problem, which must be discussed here, is the degree of craftsmanship reflected in the Fofanovo 13 assemblage. As it has been demonstrated, the average skill was definitely higher than our own, but the percentage of spoilage was still high. Partly this can be explained by the properties of the raw material, which is very difficult to work with. But this situation, in our opinion, also has to do with the fact that expert and novice knappers were working hand to hand. This is what has to be expected considering the role of teaching and hard training for developing excellent knapping skills required for sophisticated technologies (Pelegrin 1990; Apel 2001: 113-115).

\section{Acknowledgements}

We would like to express our gratitude to Alexander Zhulnikov from Petrozavodsk State University and prof. Aivar Kriiska from Tartu University for long-term support of these investigations, Michail Zobkov from Karelian Research Centre for great help in developing the technique of mass-analysis.

\section{References}

Andrefsky, W. Jr., 1998, Lithics. Macroscopic Approaches to Analysis. Cambridge University Press, Cambridge, 258 p.

Apel, J. 2001, Daggers knowledge and power: The social aspects of flint dagger technology in Scandinavia (2350-1500 cal BC). Wikströms, Uppsala, 363 p.

Äyräpää, A. 1944, Itä-Karjala kivikautisen asekaupan keskustan. Tuloksia Kansallismuseon itäkarjalaisten kokoelmien tutkimuksista. - Muinaista ja vanhaa Itä-Karjalaa. Tutkielmia Itä-Karjalan esihistoria, kulttuurihistorian ja kansankulttuurin alalta. Korrehtuurivedos. Manuscript in the National Board of Antiquities of Finland. (in Finnish) ("East Karelia as the centre of Stone Age arms trade. Results of studying the East Karelian collections of the National Museum. - Ancient and old East Karelia. Papers from the fields of prehistory, cultural history and folk culture. Correction print")

Barzilai, O. 2010, Social complexity in the Southern Levantine PPNB as reflected through lithic analysis, BAR International Series Vol. 2180, Archaeopress, Oxford, 194 p.

Bickler, S.H. \& Turner, M. 2002, Food to stone: Investigations at the Suloga adze manufacturing sites, Woodlark Island, Papua New Guinea. The Journal of the Polynesian Society, 111(1): 11-43. URL: http://www.jstor.org/stable/20707040

Bronk Ramsey, C. 2005, OxCal (computer programm). Version 3.10. The Manual. URL: http://c14.arch.ox.ac.uk/oxcal3/oxcal.htm Assessed: 01.03.2014

Bryusov, A.Y. 1947, Археологические памятники III - I тысячелетий до нашей эры в карело-Финской CCP. In: Археологический сборник. (Bryusov, A.Y., Ed.), Государственное издательство Карело-Финской ССР, Petrozavodsk: p. 9-34. (in Russian) ("Archaeological sites of the III - I thousand years BC in Karelian-Finnish SSR")

Bryusov, A.Y. 1952, Очерки по истории племён Европейской части СССР 8 неолитическую эпоху, Изд. АН СССР, Moscow, 260 p. (in Russian) ("Essays on the history of tribes in the European part of the USSR in the Neolithic epoch")

Clark, J.G.D. 1953, Доисторическая Европа: Экономический очерк. Издательство иностранной литературы, Moscow, 322 p. (in Russian) ("Prehistoric Europe: The economic basis") 
Costopoulos, A., Vaneeckout, S., Okkonen, J., Hulse, E., Paberzyte, I. \& Wren, C. 2012, Social Complexity in the Mid-Holocene North-Eastern Bothnian Gulf. European Journal of Archaeology, 15(1): 41-60. doi:10.1179/1461957112Y.0000000005

Filatova, V.F. 1971, Русско-карельский тип орудий в неолите Карелии. Советская археология, 2: 32-38. (in Russian) ("Russian Karelian type of tools in the Neolithic in Karelia")

Foss, M.E. 1952, Древнейшая история Севера европейской части СССР, Материалы и исследования по археологии CCCP, Vol. 29, Изд. АН CCCP, Moscow, 280 p. (in Russian) ("Ancient history of the Northern European part of the USSR")

Gurina, N.N. 1974, К вопросу об обмене в неолитическую эпоху. , Краткие сообщения института археологии, 138: 12-23. ("On the question of exchange in the Neolithic epoch")

Halen, O. 1994, Sedentariness during the Stone Age of Northern Sweden in the light of the Alträsket site, c. 5000 B.C., and the Comb Ware site Lillberget, c. 3900 B.C. Source critical problems of representativity in archaeology. Acta Archaeologica Lundensia. Series in 4o, No. 20. Almqvist \& Wiksell, Stockholm, 290 p.

Hansen, P.V. \& Madsen B. 1983, An experimental investigation of a flint axe manufacture site at Hastrup Vaenget, East Zealand. Journal of Danish Archaeology, 2: 43-59. doi: $10.1080 / 0108464 X .1983 .10589891$

Heikkurinen, T. 1980, Itäkarjalaiset tasa- ja kourutaltat. Helsingin yliopiston arkeologian laitus Vol. 21, Helsingin yliopisto, Helsinki, 101 p. (in Finnish) ("Eastern Karelian chisels and gouges')

Karjalainen, T. 1999, Sedentariness and dating Stone Age houses and sites. In: Dig it all. Papers dedicated to Ari Siriäinen, (Huure, M., Ed.), The Finnish Antiquarian Society and The Archaeological Society of Finland, Helsinki: p.185-190.

Katiskoski, K. 2002, The Semisubterranean dwelling at Kärmelahti in Puumala, Savo province, Eastern Finland. In: Huts and Houses: Stone Age and Early Metal Age buildings in Finland, (Ranta H., Ed.), National Board of Antiquities, Jyvaskyla: p. 171200.

Koivunen, P. 1997, Teoria jätinkirkkojen käyttötarkoituksesta. Muinaistutkija, 4: 49-52. (in Finnish) ('Theory of giant's churhes' purpose of use")

Kosmenko, M.G. 2003, Проблемы датирования и хронология памятников Карелии (каменный, бронзовый, железный века). Российская археология, 4: 25-35. (in Russian) ("Problems of dating and chronology of Karelian sites (Stone, Bronze and Iron Age)")

Kotivuori, H. 1993, Pohjanlahden kiveliöt muinaisen toiminnan tyyssijoina. Lapinraunioita ja hiidenkiukaita, Julkaisu. Museovirasto, arkeologian osasto, 3: 17-30. (in Finnish) ("Wilderness tracts of Gulf of Bothnia as centres of activities. Lapp cairns and barrows")

Kriiska, A. \& Tarasov, A. 2011, Wood-chopping tools of Russian-Karelian type from Latvia. Arheologija Un Etnografija, 25: 57-72

Kriiska, A., Tarasov, A. \& Kirs, Ju. 2013, Wood-chopping tools of Russian-Karelian type from Estonia. In: Man, his time and space. Collection of articles dedicated to Richard Indreko (Johanson, K. \& Tõrv, M., Eds.). Muinasaja teadus Vol. 19, Tartu: p. 317-345 
Lahtinen, M \& Rowley-Conwy, P. 2013, Early Farming in Finland: Was there Cultivation before the Iron Age (500 BC). European Journal of Archaeology, 16(4): 660-684. doi: $10.1179 / 1461957113$ Y.000000000040

Le Roux, C-T. 1979, Stone axes of Brittany and the Marches. In: Stone axe studies: Archaeological, petrological, experimental, and ethnographic (Mackenzie-Clough T.H. \& W.A. Cummins, Eds.), Henry Ling Ltd., London: p.49-56

Leskinen, S. 2002, The Late Neolithic House at Rusavierto. In: Huts and Houses: Stone Age and Early Metal Age buildings in Finland, (Ranta H., Ed.), National Board of Antiquities, Jyvaskyla: p. 147-170

Madsen, B. 1984, Flint axe manufacture in the Neolithic: experiments with grinding and polishing of thin-butted axes. Journal of Danish Archaeology, 3(3): 47-62. doi:10.1080/0108464X.1984.10589911

Mallory, J.K. 1986, "Workshops" and "specialized production" in the production of Maya chert tools: A response to Shafer and Hester. American Antiquity, 51(1): 152-158. URL: http://www.jstor.org/stable/280401

Mökkönen, T. 2010, Kivikautinen maanviljely Suomessa. Suomen Museo, 2009: 5-38. (in Finnish) ("Neolithic cereal cultivation in Finland")

Mökkönen, T. 2011, Studies on Stone Age housepits in Fennoscandia (4000 - 2000 cal BC): Changes in ground plan, site location, and degree of sedentism, Unigrafia, Helsinki, $86 \mathrm{p}$.

Nordquist, K. \& Seitsonen, O. 2008, Finnish Archaeological Activities in the Present-Day Karelian Republic until 1944. Fennoscandia Archaeologica, 25: 27-60.

Nordqvist, K. \& Herva, V. 2013, Copper Use, Cultural Change and Neolithization in NorthEastern Europe (c. 5500-1800 BC). European Journal of Archaeology, 16(3): 401-432. doi: $\underline{10.1179 / 14619113 \text { Y.0000000036 }}$

Odell, G.H. 2004, Lithic Analysis, Manuals in archaeological method, theory, and technique. Kluwer Academic/Plenum Publishers, New York, 262 p.

Pelegrin, J. 1990, Prehistoric lithic technology: Some aspects of research. Archaeological review from Cambridge, 9(1): 116-125.

Pelegrin, J. 2002, La production des grandes lames de silex du Grand-Pressigny. In: Matériaux, productions, circulations, du Néolithique à l'Age du bronze, (Guilaine J., Ed.), Errance, Paris: p. 125-141 (in French) ("Production of long flint blades in GrandPressigny")

Pelegrin, J.P. 2004, Blade-making techniques from the Old World. Lights and applications to Mesoamerican obsidian Lithic technology. In: Mesoamerican lithic technology. Experimentation and interpretation, (Hirth, F.G., Ed.), University of Utah Press, Salt Lake City: p. 55-71.

Pesonen, Paula E. 1982, Мезолитическое поселение Суна XIII. In: Поселения каменного века и раннего металла в Карелии, (Pankrushev G.A., Ed.), КФ АН СССР, Petrozavodsk: p. 31-51. (in Russian) (“Mesolithic settlement Suna XIII”)

Pesonen, Paula E. 1984, Стоянка-мастерская в низовье р. Суны. In: Археологические памятники бассейна Онежского озера, (Pankrushev G.A., Ed.), КФ АН СССР, Petrozavodsk: p.98-120. (in Russian) ("Workshop site in lower reaches of Suna River") 
Pesonen, Petro 1996, Archaeology of the Jaamankangas area - with special reference to the Rääkkylä Pörrinmökki Stone Age settlement site. In: Environmental Studies in Eastern Finland. Reports of the Ancient Lake Saimaa Project, (Kirkinen T., Ed.), Helsinki Papers in Archaeology Vol. 8, Yliopistopaino, Helsinki: p. 93-117.

Pesonen, Petro 2006, One house - two households? An investigation of a Late Subneolithic pithouse in Kuorikkikangas site, Posio, southern Lapland. In: People, Material Culture and Environment in the North. Proceedings of the 22nd Nordic Archaeological Conference, University of Oulu, 18-23 August 2004, (Herva V., Ed.), University of Oulu, Oulu: p. 198-213.

Petrequin, P., Petrequin, A.-M., Jeudy, F., Jeunesse, Ch., Monnier, J.-L., Pelegrin, J. \& Praud, I. 1998, From the raw material to the Neolithic stone axe: Production processes and social context. In: Understanding the Neolithic of North-Western Europe, (Edmonds M.R. \& Richards C, Eds.), Cruithne Press, Glasgow: p. 277-311.

Reimer, P. J., Baillie, M. G. L., Bard, E., Bayliss, A., Beck, J. W., Bertrand, C. J. H., Blackwell, P. G., Buck, C. E., Burr, G. S., Cutler, K. B., Damon, P. E., Edwards, R. L., Fairbanks R. G., Friedrich, M., Guilderson, T. P., Hogg, A. G., Hughen, K. A., Kromer, B., McCormac, G., Manning, S., Ramsey, C. B., Reimer, R. W., Remmele, S., Southon, J. R., Stuiver, M., Talamo, S., Taylor, F. W., van der Plicht, J. \& Weyhenmeyer, C. E. 2004, IntCal04 terrestrial radiocarbon age calibration, 0-26 cal kyr BP. Radiocarbon, 46 (3): 1029-1058. doi:10.2458/azu_js_rc.46.4167

Savvateev, J.A. \& Vereschagin, N.K. 1978, Охотничье-промысловые животные и каменный инвентарь населения Карелии и южной части Кольского полуострова эпохи неолита и раннего металла. In: Мезолитические памятники Карелии, (Savvateev Ju.A., Ed.), КФ AH CCCP, Petrozavodsk: p. 181-215. (in Russian) ("Hunting prey animals and lithic inventory of inhabitants of Karelia and southern part of Kola Peninsula in the Neolithic - the Early metal period")

Shafer, H.J. \& Hester, T.R. 1986, Maya stone-tool craft specialization and production at Colha, Belize: Reply to Mallory. American Antiquity, 51(1): 158-166. URL: http://www.jstor.org/stable/280402

Shafer H.J. \& Hester T.R. 1991, Lithic craft specialization and product distribution at the Maya site of Colha, Belize. World Archaeology, 23(1): 79-97. doi: $\underline{10.1080 / 00438243.1991 .9980160}$

Sundström, L., 2003, Det hotade kollektivet: Neoliseringsprocessen ur ett ostmellansvenskt perspektiv. Wikströms, Uppsala, 321 p. (in Swedish) ("The threatened collective: Processes of Neolithization from the perspective of eastern central Sweden")

Sundström, L., Apel, J., 1998, An Early Neolithic axe production and distribution system within a semi-sedentary farming society in eastern central Sweden, c.3500 BC. In: Third flint alternatives conference at Uppsala, (Holm L. \& Knutsson K., Eds.), Occasional papers in archaeology Vol. 16, Uppsala University, Uppsala: p. 155-192

Tallgren, A.M. 1922, Zur Archäologie Eestis, I. Vom anfang der Besiedlung bis etwa $500 \mathrm{n}$. Chr. Acta et Commentationes Universitatis Tartuensis (Dorpatensis), B III: 6, Dorpat (in German) ("Estonian Archaeology, I. From initial inhabiting till ca. 500 AD")

Tarasov, A.Y., Kriiska, A. \& Kirs, Yu. 2010, Свидетельства обмена между населением Карелии и Эстонии в финальном каменном веке: по результатам археологического и петрографического изучения рубящих орудий русско- 
карельского типа с территории Эстонии, Труды Карельского научного центра PAH 4: 56-65. (in Russian) ("Evidences of exchange between inhabitants of Karelian and Estonia in the Final Stone Age: basing on results of archaeological and petrological studies of chopping tools of the Russian Karelian type from the territory of Estonia")

Tarasov, A.Y. \& Zobkov, M.B. 2013, Методика потокового анализа продуктов расщепления камня с использованием программ распознавания изображений. Археологические Вести, 19: 195-210. (in Russian) (Mass-analysis of chipped stone assemblages with the aid of image recognition software)

Tarasov, A.Y. 2003, Центр изготовления каменных макроорудий энеолитического времени на территории Карелии. Археологические Вести, 10: 60-74. (in Russian) ("A centre of manufacture of stone macrotools of Eneolithic period in Karelia")

Tarasov, A.Y. 2006, Некоторые особенности социально-экономического развития населения Карелии в неолите - раннем железном веке. In: Проблемь этнокультурной истории населения Карелии (мезолит - средневековье), (Kochkurkina S.I. \& Kosmenko M.G., Eds.), ИЯЛИ КарНЦ РАН, Petrozavodsk: p. 73112. (in Russian) ("Some traits of socio-economic development of inhabitants of Karelia in the Neolithic - the Early Iron Age")

Tarasov, A.Y. 2008, Энеолитическая индустрия макроорудий Карелии в ряду европейских индустрий позднего каменного века. In: Хронология, периодизация и кросс-культурные связи в каменном веке. Замятнинский сборник вып. 1, (Chlopachev G.A., Ed.), Наука, Saint Petersburg: p. 190-201. (in Russian) ("Eneolithic macrotool industry in Karelia among European industries in the Late Stone Age")

Tarasov, A.Y. 2011a, Каменная индустрия Оленеостровской мезолитической стоянки в окрестностях острова Кижи: Технико-типологический анализ. Кижский Вестник, 13: 211-272. (in Russian) ("Lithic industry of Oleneostrovskaya Mesolithic settlement site in the vicinity of Kizhi Island")

Tarasov, A.Y. 2011b, Отчёт об археологических работах в Прионежском и Пряжинском районах Республики Карелия в 2010 г., Petrozavodsk, Unpublished research report. (in Russian) ("Report on archaeological fieldworks in Prionezhsky and Pryazhinsky districts of the Republic of Karelia in 2010")

Tarasov, A.Y. 2012, Отчёт о раскопках энеолитической стоянки-мастерской Фофаново ХІІІ в Прионежском районе Республики Карелия в 2011 г., Petrozavodsk, Unpublished research report. (in Russian) ("Report on excavations of Eneolithic workshop site Fofanovo XIII in Prionezhsky district of the Republic of Karelia in 2011")

Tarasov, A.Y., Murashkin, A.I. \& German, K.Е. 2007, Новые исследования на Южном Оленьем острове Онежского озера. In: Кольский Сборник (Shayachmetova L.G., Еd.). ИИМК РАН, Санкт-Петербург: p. 41-82. (in Russian) ("New investigations in Yuzhny Oleny Island in Onega Lake")

Tarasov, A.Y., Kriiska, A. \& Kirs, Yu.. 2010, Свидетельства обмена между населением Карелии и Эстонии в финальном каменном веке: по результатам археологического и петрографического изучения рубящих орудий русскокарельского типа с территории Эстонии, Труды Карельского научного центра $P A H$, 4: 56-65. (in Russian) ("Evidences of exchange between inhabitants of Karelian and Estonia in the Final Stone Age: basing on results of archaeological and petrological studies of chopping tools of the Russian Karelian type from the territory of Estonia"). 
Torrence, R. 1984, Monopoly or direct access? Industrial organization at the Melos obsidian quarries. In: Prehistoric Quarries and Lithic Production, (Ericson E. \& Purdy B., Eds.), Cambridge University Press, Cambridge: p.49-64.

Ukkonen, P. 1996, Osteological analysis of the refuse fauna in the Lake Saimaa area. In: Environmental Studies in Eastern Finland. Reports of the Ancient Lake Saimaa Project, (Kirkinen T., Ed.). Helsinki Papers in Archaeology Vol. 8, Yliopistopaino, Helsinki: p. 63-91.

Whittaker, J. C., Kamp, K.A., Ford, A., Guerra, R., Brands, P., Guerra, J., McLean, K., Woods, A., Badillo, M., Thornton, J. \& Eiley, Z. 2009, Lithic industry in a Maya center: An axe workshop at El Pilar, Belize. Latin American Antiquity, 20(1): 134-156. URL: http://www.jstor.org/stable/40650080

Zhulnikov, A. \& Spiridonov, A. 2003, Древности Петрозаводска, Скандинавия, Petrozavodsk, 130 p. (in Russian) ("Antiquities of Petrozavodsk")

Zhulnikov, A., Tarasov, A. \& Kriiska, A. 2012, Discrepancies between conventional and AMS dates of complexes with Asbestos and Porous Ware - probable result of "reservoir effect"?. Fennoscandia Archaeologica, 29: 79-86.

Zhulnikov, A.M. 1999, Энеолит Карелии: Памятники с пористой и асбестовой керамикой, ИЯЛИ КарНЦ РАН, Petrozavodsk, 224 p. (in Russian) ("Eneolithic in Karelia: Sites with Asbestos and Porous Ware")

Zhulnikov, A.M. 2003, Древние жилища Карелии. КГКМ, Petrozavodsk, 199 p. (in Russian) ("Ancient dwellings in Karelia") 
